\title{
Macroalgae from 23 Stream Segments in the Hawaiian Islands ${ }^{1}$
}

\author{
Nanda R. Filkin, ${ }^{2}$ Alison R. Sberwood, ${ }^{3}$ and Morgan L. Vis ${ }^{2}$
}

\begin{abstract}
Twenty-three stream segments (seven on $\mathrm{O}^{6}$ ahu, eight on Kaua'i, and eight on Hawai ${ }^{i}$ ) were sampled for macroalgae in the Hawaiian Islands. Stream segments ranged greatly in size from 1.2 to $40 \mathrm{~m}$ in width. Water temperature was uniformly warm $\left(17-24^{\circ} \mathrm{C}\right)$, but other chemical parameters differed from site to site ( $\mathrm{pH} 5.5-8.9$, specific conductance $20-200 \mu \mathrm{S} \cdot \mathrm{cm}^{-1}$ ). Mean species richness per site was 3.9 with one to eight species collected per stream segment. Ninety populations of 42 infrageneric taxa were identified from the Cyanobacteria (19), Chlorophyta (17), Rhodophyta (3), and Chrysophyta (3). The most abundant taxa were Spirogyra sp. 1, Audouinella pygmaea, and Phormidium retzii. All three of these taxa are widespread among the Islands. Other species collected on all three islands were Cloniophora plumosa and Hildenbrandia angolensis. Eighteen taxa are new records for streams and 15 of these for aquatic habitats. Ten of the new records for the Hawaiian Islands were collected on Kaua'i, six on O'ahu, and one on Hawai' $i$ (two new records shared for Kaua $i$ and $\mathrm{O}^{6} \mathrm{ahu}$ ). The large percentage $(36 \%)$ of new taxa reported in this study suggests that more research is needed to fully catalog the Hawaiian stream macroalgal diversity. This study extends the number of micro- and macroalgal taxa known from streams in the Hawaiian Islands to 299 infrageneric taxa.
\end{abstract}

The Hawailan Islands are at least 3700 $\mathrm{km}$ from the continental landmasses of Asia, Australia, North America, and South America (Maciolek 1969). Volcanic oceanic islands, such as the Hawaiian Archipelago, derive their entire flora and fauna from immigrants capable of long-distance dispersal or their descendents (Pielou 1979). Typically, islands such as these have lower species richness than continental landmasses due to difficulties of long-distance dispersal (Schoener 1988). For freshwater algae to colonize these islands, wind or bird dispersal must be relied upon, which may limit taxon richness. However, a

${ }^{1}$ Manuscript accepted 18 March 2003.

2 Department of Environmental and Plant Biology, Ohio University, Athens, Ohio 45701 (E-mail: nf160798@ ohio.edu and vis-chia@ohio.edu).

${ }^{3}$ Department of Botany, University of Hawai'i at Mảnoa, Honolulu, Hawaiłi 96822 (E-mail: asherwoo@ hawaii.edu).

Pacific Science (2003), vol. 57, no. 4:421-431

(C) 2003 by University of Hawai'i Press

All rights reserved preliminary study of stream macroalgae revealed a slightly higher mean species richness per stream segment for the Hawaiian Islands in comparison with North American streams as a whole and tropical North America in particular (Vis et al. 1994). Therefore, it appears that the distance is not as substantial a barrier as might be predicted for this group of organisms.

There have been a few historical surveys on the freshwater algae of the Hawaiian Islands from various habitats (e.g., Tilden 1902, MacCaughey 1917, 1918a,b). Only one survey to date has focused solely on stream habitats (Vis et al. 1994). Although the previous study of stream macroalgae was preliminary, sampling 34 streams, it yielded 25 new taxonomic records for stream habitats and one species of Batrachospermum (Rhodophyta) new to science. Two other recent reports focusing on macroalgae taxa have identified new records for the Chlorophyta and Cyanobacteria of the Islands (Sherwood et al. $2001 a, b)$. Therefore, the study reported here was initiated to build on the recent research in macroalgae and expand our knowledge of 
algal diversity in the Hawaiian Islands by sampling more stream segments and concentrating on more remote locations.

\section{MATERIALS AND METHODS}

Twenty-three stream segments were sampled during 2-21 August 2001, including seven stream segments from $O^{\prime}$ ahu and eight each from Kaua'i and Hawai'i (Figure 1). At each site, a minimum of $20 \mathrm{~m}$ of stream length was surveyed for macroalgae (algae visible with the naked eye), and algal cover was estimated for each taxon as described previously (Sheath et al. 1986). Representative samples of each taxon encountered were immediately fixed in $2.5 \%$ calcium carbonate-buffered glutar- aldehyde for later identification. Latitude, longitude, and elevation were obtained using a portable GPS unit (Trimble Scoutmaster) for most locations (Table 1). Within the sampling area, the maximum width and depth were determined and water temperature measured. Water color was noted as clear, yellow, or brown by visual inspection only. Water $\mathrm{pH}$ was measured using a pHTester 2 and specific conductance with TDSTestr 3. Mean current velocity was calculated from three measurements using a flow meter (General Oceanics Model 2030) or in lowflow environments by timing the movement of a bobber over a 1-m length.

Discrete entities from the field notes were separated using a stereoscope (Olympus

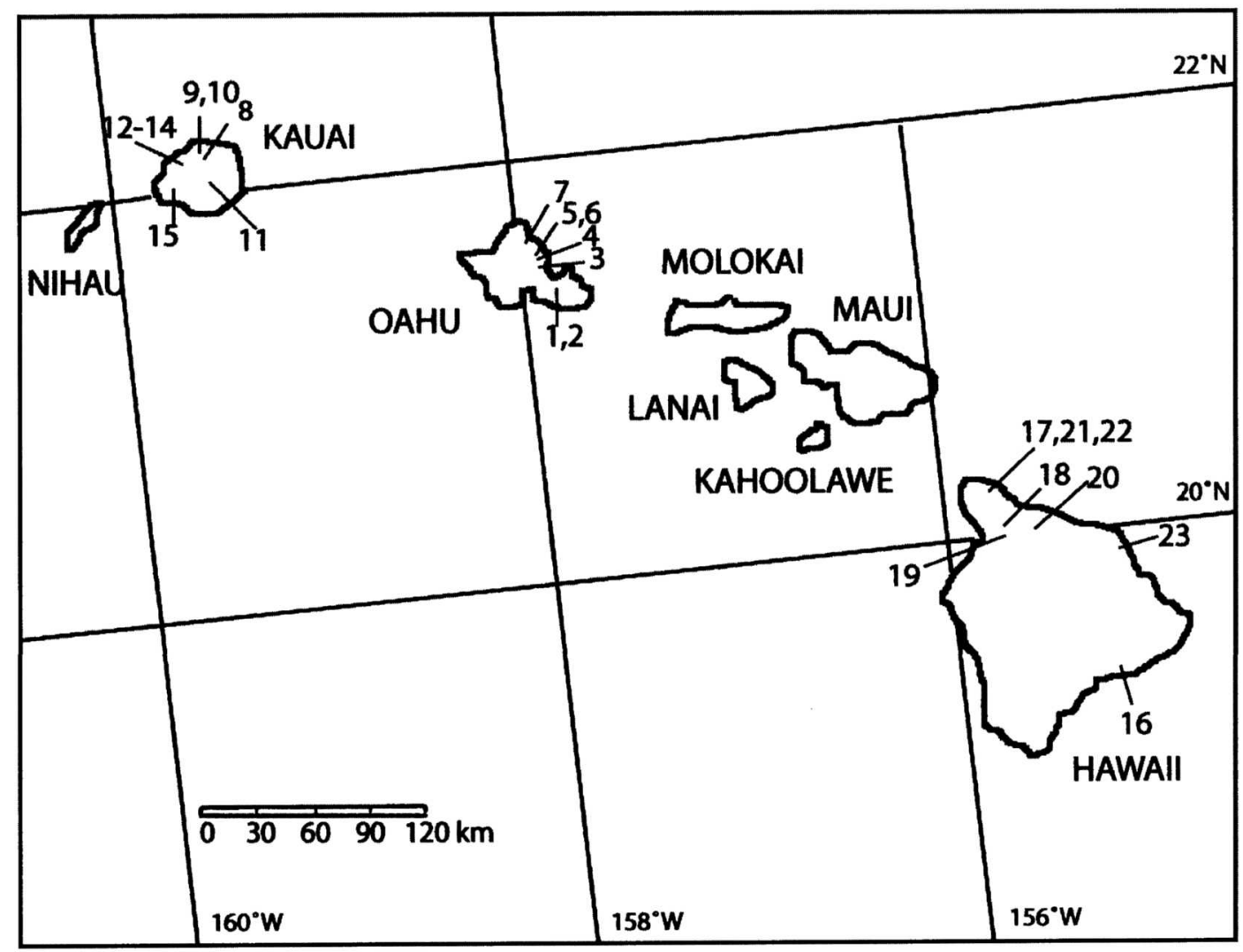

FIgURE 1. Map of stream segments sampled in the Hawaiian Islands. Numbers correspond to stream numbers in Table 1. 
TABLE I

Physical and Chemical Characteristics from 23 Hawaiian Streams

\begin{tabular}{|c|c|c|c|c|c|c|c|c|c|c|c|c|}
\hline \multirow[b]{2}{*}{$\begin{array}{l}\text { Stream } \\
\text { No. }{ }^{a}\end{array}$} & \multirow[b]{2}{*}{ Island } & \multirow{2}{*}{$\begin{array}{l}\text { Max. } \\
\text { Width } \\
\text { (m) }\end{array}$} & \multirow{2}{*}{$\begin{array}{l}\text { Max. } \\
\text { Depth } \\
\text { (cm) }\end{array}$} & \multirow{2}{*}{$\begin{array}{c}\text { Mean } \\
\text { Current } \\
\text { Velocity } \\
\left(\mathrm{cm} \cdot \sec ^{-1}\right)\end{array}$} & \multirow[b]{2}{*}{$\begin{array}{l}\text { Temp } \\
\left({ }^{\circ} \mathrm{C}\right)\end{array}$} & \multirow[b]{2}{*}{$\mathrm{pH}$} & \multirow{2}{*}{$\begin{array}{c}\text { Specific } \\
\text { Conductance } \\
\left(\mu \mathrm{S} \cdot \mathrm{cm}^{-1}\right)\end{array}$} & \multirow[b]{2}{*}{$\begin{array}{l}\text { Water } \\
\text { Color }^{b}\end{array}$} & \multirow[b]{2}{*}{$\begin{array}{l}\text { Elevation } \\
\text { (m) }\end{array}$} & \multirow[b]{2}{*}{ Location (latitude, longitude) } & \multicolumn{2}{|c|}{ Macroalgae } \\
\hline & & & & & & & & & & & $\begin{array}{c}\text { Species } \\
\text { No. }\end{array}$ & $\begin{array}{l}\text { Cover } \\
\text { Scale }^{c}\end{array}$ \\
\hline 1 & O'ahu & 3.5 & 50 & 10 & 23 & 8.9 & 100 & 0 & - & - & 6 & 2 \\
\hline 2 & O’ahu & 1.2 & 48 & 26 & 24 & 8.5 & 200 & 0 & 341.4 & $21^{\circ} 22.034^{\prime} \mathrm{N}, 157^{\circ} 47.208^{\prime} \mathrm{W}$ & 5 & 2 \\
\hline 3 & O’ahu & 5.5 & 21 & 15 & 20 & 8.2 & 110 & 0 & 82.3 & $21^{\circ} 26.286^{\prime} \mathrm{N}, 157^{\circ} 51.475^{\prime} \mathrm{W}$ & 4 & 2 \\
\hline 4 & O'ahu & 7.2 & $>100$ & 10 & 23 & 8.2 & 190 & 0 & 9.1 & $21^{\circ} 27.977^{\prime} \mathrm{N}, 157^{\circ} 51.221^{\prime} \mathrm{W}$ & 3 & 3 \\
\hline 5 & O'ahu & 4.4 & 17 & 13 & 23 & 8.1 & 180 & - & 73.2 & $21^{\circ} 29.065^{\prime} \mathrm{N}, 157^{\circ} 52.163^{\prime} \mathrm{W}$ & 3 & 2 \\
\hline 6 & O'ahu & 5.55 & 30 & 14 & 21 & 8.2 & 110 & - & - & $21^{\circ} 29.065^{\prime} \mathrm{N}, 157^{\circ} 52.163^{\prime} \mathrm{W}$ & 4 & 2 \\
\hline 7 & O'ahu & 16.9 & $>100$ & 10 & 23 & 7.8 & 120 & 0 & 24.4 & $21^{\circ} 32.433^{\prime} \mathrm{N}, 157^{\circ} 52.873^{\prime} \mathrm{W}$ & 5 & 3 \\
\hline 8 & Kaua $i$ & 7.8 & $<100$ & 13 & 24 & 7.8 & 90 & 0 & 36.6 & $22^{\circ} 11.780^{\prime} \mathrm{N}, 159^{\circ} 31.059^{\prime} \mathrm{W}$ & 8 & 6 \\
\hline 9 & Kaua'i & 6.4 & $>100$ & 13 & 22 & 8.4 & 80 & 0 & - & $22^{\circ} 13.075^{\prime} \mathrm{N}^{\prime}, 159^{\circ} 34.541^{\prime} \mathrm{W}$ & 5 & 5 \\
\hline 10 & Kauái & 3 & 39.2 & 8 & 23 & 8.1 & 140 & 0 & 15.2 & $22^{\circ} 13.174^{\prime} \mathrm{N}, 159^{\circ} 33.842^{\prime} \mathrm{W}$ & 2 & 1 \\
\hline 11 & Kaua $\mathbf{i}$ & 24.1 & $>100$ & 9 & 22 & 8.1 & 90 & 0 & 170.7 & $22^{\circ} 04.281^{\prime} \mathrm{N}, 159^{\circ} 24.968^{\prime} \mathrm{W}$ & 8 & 5 \\
\hline 12 & Kauaci & 5.6 & $>100$ & 12 & 17 & 5.5 & 20 & 2 & $1,109.5$ & $22^{\circ} 08.781^{\prime} \mathrm{N}, 159^{\circ} 36.743^{\prime} \mathrm{W}$ & 2 & 5 \\
\hline 13 & Kaua $\mathrm{i}$ & 4.2 & $<100$ & 14 & 19 & 6.3 & 20 & 2 & - & $22^{\circ} 07.864^{\prime} \mathrm{N}, 159^{\circ} 37.803^{\prime} \mathrm{W}$ & 4 & 5 \\
\hline 14 & Kaua $\mathrm{i}$ & 10.3 & $>100$ & 14 & 19 & 5.7 & 20 & 2 & $1,057.7$ & $22^{\circ} 07.882^{\prime} \mathrm{N}, 159^{\circ} 37.212^{\prime} \mathrm{W}$ & 4 & 4 \\
\hline 15 & Kaua'i & 1.31 & 72 & 14 & 21 & 6.7 & 20 & 2 & 914.4 & $22^{\circ} 03.502^{\prime} \mathrm{N}, 159^{\circ} 39.749^{\prime} \mathrm{W}$ & 3 & 5 \\
\hline 16 & Hawaici & 4 & 65 & 14 & 20 & 8.1 & 80 & 0 & 387.1 & $19^{\circ} 15.322^{\prime} \mathrm{N}, 155^{\circ} 08.988^{\prime} \mathrm{W}$ & 2 & 6 \\
\hline 17 & Hawai'i & 7 & 40 & 15 & 24 & 8.0 & 90 & 0 & 76.2 & $20^{\circ} 13.142^{\prime} \mathrm{N}, 155^{\circ} 45.256^{\prime} \mathrm{W}$ & 5 & 3 \\
\hline 18 & Hawai'i & 3.2 & 26 & 15 & 19 & 7.4 & 30 & 2 & $1,103.4$ & $20^{\circ} 05.382^{\prime} \mathrm{N}, 155^{\circ} 45.469^{\prime} \mathrm{W}$ & 2 & 5 \\
\hline 19 & Hawaiti & 5 & $<100$ & 9 & 22 & 6.7 & 20 & 2 & 771.1 & $20^{\circ} 01.661^{\prime} \mathrm{N}, 155^{\circ} 41.784^{\prime} \mathrm{W}$ & 1 & 1 \\
\hline 20 & Hawai ${ }^{6} i$ & 40 & $>100$ & 13 & 23 & 7.2 & 140 & 0 & - & $20^{\circ} 07.111^{\prime} \mathrm{N}, 155^{\circ} 35.355^{\prime} \mathrm{W}$ & 4 & 3 \\
\hline 21 & Hawai'i & 7.1 & $>100$ & 10 & 22 & 7.6 & 90 & 0 & - & $20^{\circ} 13.520^{\prime} \mathrm{N}, 155^{\circ} 44.680^{\prime} \mathrm{W}$ & 4 & 4 \\
\hline 22 & Hawaici & 11.1 & $<100$ & 10 & 21 & 7.6 & 60 & 1 & 134.1 & $20^{\circ} 12.481^{\prime} \mathrm{N}, 155^{\circ} 44.275^{\prime} \mathrm{W}$ & 3 & 3 \\
\hline 23 & Hawai'i & 20 & $<100$ & 14 & 22 & 7.6 & 50 & 0 & - & $19^{\circ} 49.194^{\prime} \mathrm{N}, 155^{\circ} 05.59^{\prime} \mathrm{W}$ & 3 & 3 \\
\hline
\end{tabular}

"For details see Appendix.

0 , colorless; 1 , yellow; 2 , brown.

$0,0 \% ; 1,<1 \% ; 2,1-10 \% ; 3,11-25 \% ; 4,26-50 \% ; 5,51-75 \% ; 6,76-100 \%$ (Sheath et al. 1986). 
SZH-ILLD). Macroalgal specimens were identified to species level, when possible, using a compound light microscope (Olympus BX40). Algal keys such as Geitler (1932), Prescott (1962), and Islam (1963) were used with the taxonomy updated as necessary. Pearson and Spearman correlations were performed for all stream variables, species richness, and algal percentage cover to determine any significant trends using NCSS (Hintze 2000).

\section{RESULTS}

The 23 stream segments sampled varied in physical and chemical parameters (Table 1). Streams were $1.2-40 \mathrm{~m}$ in width and 17$>100 \mathrm{~cm}$ in depth. Current velocities tended to be slow, ranging from 8.3 to 26.4 $\mathrm{cm} \cdot \mathrm{sec}^{-1}$. Water temperature was warm (17$\left.24^{\circ} \mathrm{C}\right)$. The $\mathrm{pH}$ ranged from acidic to alkaline (5.5-8.9), and specific conductance was low to moderate $\left(20-200 \mu \mathrm{S} \cdot \mathrm{cm}^{-1}\right)$. These two parameters were positively correlated $(P<0.05)$, but they were the only correlated physical and chemical characteristics. Water color was clear in most streams, and only a few streams were slightly turbid (Table 1). The elevations that could be determined were from 9.1 to $1103.4 \mathrm{~m}$ above sea level. The mean species richness per stream segment for the three islands combined was 3.9 and ranged from one to eight species per stream segment. Algal cover ranged from $<1$ to $>76 \%$. Species number per stream segment and algal cover were not correlated $(P>$ $0.05)$ to each other or to any of the physical and chemical parameters measured.

The seven stream segments sampled on O'ahu varied in all physical and chemical parameters measured with the exception of water color (Table 1). A variety of stream habitats were present, ranging from fast, small rivulets (stream 2) to wide, slow-moving rivers (stream 7 ). All streams had an alkaline $\mathrm{pH}(7.8-8.9)$, moderate specific conductance $\left(100-200 \mu \mathrm{S} \cdot \mathrm{cm}^{-1}\right)$, and clear water. The number of species per stream segment varied from three to six with a mean of 4.2 . The algal cover for all streams was $<25 \%$ of the stream bottom. Overall, 30 macroalgal samples were collected and 22 species were identified (Table 2). Six of these species are new records for aquatic habitats in the Hawaiian Islands.

The eight stream segments sampled on Kaua' $i$ ranged greatly in maximum stream width and depth (Table 1). Mean current velocity ranged from 8.3 to $13.4 \mathrm{~cm} \cdot \mathrm{sec}^{-1}$, and temperatures were warm $\left(17-24^{\circ} \mathrm{C}\right)$. Four of the streams sampled were in highelevation bog areas. These streams had an acidic-neutral pH (5.5-6.7), tannic waters (brown colored), and low specific conductance $\left(20 \mu \mathrm{S} \cdot \mathrm{cm}^{-1}\right)$. The other four streams had alkaline $\mathrm{pH}(7.8-8.4)$ with clear water and higher specific conductance (80-140 $\left.\mu \mathrm{S} \cdot \mathrm{cm}^{-1}\right)$. Species richness ranged from two to eight species per segment with a mean of 4.5. Macroalgal percentage cover of stream bottom ranged greatly $(<1->76 \%)$. On this island, a total of 25 species was identified from 36 macroalgal samples, of which 10 species were new records for the Hawaiian Islands (Table 2).

On the island of Hawai' $i$, eight stream segments were sampled and were highly variable in physical attributes, with maximum width ranging from 3.2 to $40 \mathrm{~m}$ and depth ranging from 26 to $>100 \mathrm{~cm}$ (Table 1). The streams were similar in chemical attributes to those on $\mathrm{O}^{\prime}$ ahu and most of Kaua' $\mathrm{i}$ in having neutral to alkaline $\mathrm{pH}(6.7-8.1)$ and low to moderate specific conductance values (20$\left.140 \mu \mathrm{S} \cdot \mathrm{cm}^{-1}\right)$. One to five species were collected in each stream segment, and the mean species richness was 3.0. Percentage cover of stream bottom by macroalgae varied from sparse to heavy ( $<1$ to $>76 \%$ ). Overall, 12 species were identified from 24 macroalgal samples, with only one new record (Ulotbrix tenuissima) (Table 2). All of the other species identified from this island were cosmopolitan in the Hawaiian Island chain.

In total, 90 macroalgal samples of 42 infrageneric taxa were identified from the 23 stream segments. The greatest number of samples was collected on Kaua'i (36), followed by O'ahu (30) and Hawai'i (24) (Table 
TABLE 2

Distribution of Macroalgal Species Collected in the Hawaiian Islands

\begin{tabular}{|c|c|c|c|c|}
\hline \multirow[b]{2}{*}{ Taxon } & \multicolumn{3}{|c|}{ Island } & \multirow{2}{*}{$\begin{array}{c}\text { Total } \\
\text { No. of } \\
\text { Streams }\end{array}$} \\
\hline & $\begin{array}{l}\text { O'ahu } \\
n=7\end{array}$ & $\begin{array}{c}\text { Kaua } \mathrm{i} \\
n=8\end{array}$ & $\begin{array}{c}\text { Hawai }{ }^{*} \mathrm{i} \\
n=8\end{array}$ & \\
\hline \multicolumn{5}{|l|}{ Cyanobacteria } \\
\hline Cylindrospermum stagnale (Kütz.) Bornet \& Flahault & & 1 & & 1 \\
\hline Cylindrospermum sp. & & & 1 & 1 \\
\hline Geitlerinema splendidum (Grev. ex Gomont) Anagn." & 1 & & 1 & 2 \\
\hline Leptolyngbya angustissima (W. West \& G. S. West) Anagn. \& Komárek ${ }^{b}$ & 1 & & & 1 \\
\hline Microchate uberrina N. Carter ${ }^{b}$ & & 1 & & 1 \\
\hline Microcoleus lacustris (Rabenh.) Farl. & & & 4 & 4 \\
\hline Nostoc linckia Roth ex Bornet \& Flahault ${ }^{a}$ & & 1 & & 1 \\
\hline Nostocbopsis lobatus Wood em. Geitler ${ }^{b}$ & & 1 & & 1 \\
\hline N. radians Bharadwaja ${ }^{b}$ & 1 & 1 & & 2 \\
\hline Oscillatoria limosa C. Agardh ex Gomont ${ }^{b}$ & 1 & 1 & & 2 \\
\hline Oscillatoria sp. & & 1 & & 1 \\
\hline Pbormidium amoenum (Kïtz. ex Gomont) Anagn. \& Komárek ${ }^{b}$ & & 1 & & 1 \\
\hline P. corium C. Agardh ex Gomont ${ }^{b}$ & 1 & & & 1 \\
\hline P. retzii C. Agardh ex Gomont & 3 & 2 & 2 & 7 \\
\hline Pseudanabaena sp. & 1 & & & 1 \\
\hline Scytonema chiastum Geiter $^{b}$ & & 1 & & 1 \\
\hline S. coactile Montagne in Kütz. ${ }^{b}$ & & 1 & & 1 \\
\hline S. tolypotbricoides Kütz. & & 1 & & 1 \\
\hline Tolypotbrix tenuis (Kütz.) em. Schmidt & 1 & & & 1 \\
\hline \multicolumn{5}{|l|}{ Chlorophyta } \\
\hline Basicladia cbelonum (Collins) W. E. Hoffm. \& Tilden & 1 & & & 1 \\
\hline Chaetophora elegans (Roth) C. Agardh ${ }^{b}$ & & 1 & & 1 \\
\hline Cladopbora fracta (Roth) Kütz. & 1 & & & 1 \\
\hline C. glomerata var. glomerata (L.) Kütz. & 3 & 2 & & 5 \\
\hline Cloniopbora plumosa (Kütz.) em. Bory & 1 & 1 & 2 & 4 \\
\hline Microspora pachyderma (Wille) Lagerh. ${ }^{b}$ & & 3 & & 3 \\
\hline Mongeotia sp. 1 & & 2 & 1 & 3 \\
\hline Oedogonium sp. 1 & 1 & & & 1 \\
\hline Oedogonium sp. 2 & 1 & & 1 & 2 \\
\hline Spirogyra sp. 1 & 2 & 3 & 4 & 9 \\
\hline Spirogyra sp. 2 & & 1 & & 1 \\
\hline Stigeoclonium lubricum (Dillwyn) Kütz. ${ }^{b}$ & 1 & & & 1 \\
\hline S. segarare A. K. Islam ${ }^{b}$ & & 1 & & 1 \\
\hline S. setigernm Kütz. & 1 & & & 1 \\
\hline S. stagnatile (Hazen) Collins & & & 2 & 2 \\
\hline S. subsecundum (Kütz.) Kütz. & & 1 & & 1 \\
\hline Ulotbrix tenuissima Kütz. ${ }^{b}$ & & & 1 & 1 \\
\hline \multicolumn{5}{|l|}{ Chrysophyta } \\
\hline Hydrosera whampoensis (Schwartz) Duby & 1 & & & 1 \\
\hline Tabellaria flocculosa (Roth) Kütz. & & 3 & & 3 \\
\hline Terpsinoe musica Ehrenb." & 1 & & & 1 \\
\hline \multicolumn{5}{|l|}{ Rhodophyta } \\
\hline Audouinella pygmaea (Kütz.) Weber Bosse & 3 & 2 & 3 & 8 \\
\hline Compsopogon coeruleus (Balb.) Mont. & 3 & 1 & & 4 \\
\hline Hildenbrandia angolensis Welw. ex W. West \& G. S. West & 1 & 2 & 2 & 5 \\
\hline Total & 30 & 36 & 24 & 90 \\
\hline
\end{tabular}

"New record for stream habitats in the Hawaiian Islands.

b New record for any habitat in the Hawaiian Islands. 

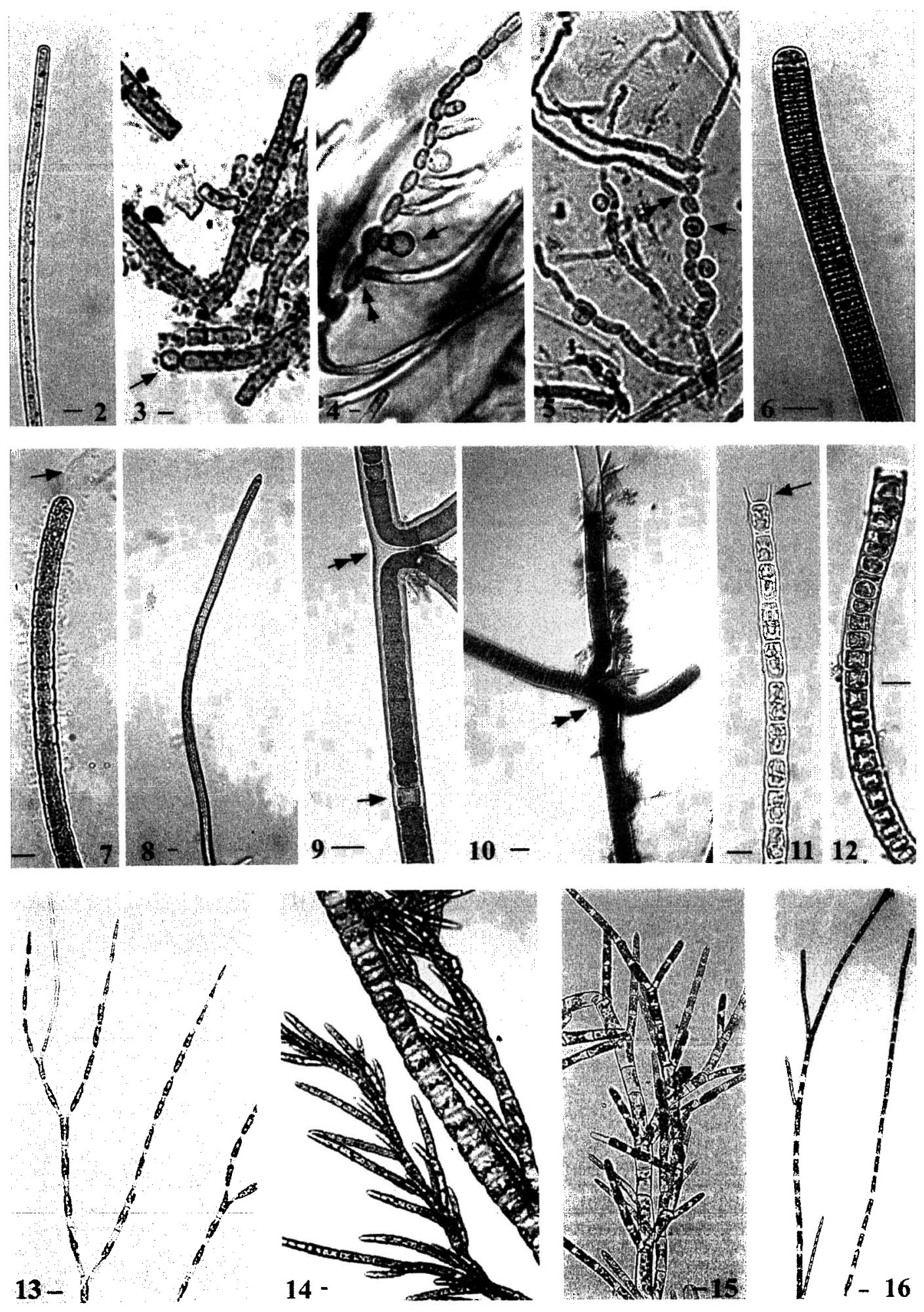
2). Overall, 19 Cyanophyta, 17 Chlorophyta, 3 Rhodophyta, and 3 Chrysophyta were identified. Of these taxa, 15 were new records for the Hawaiian Islands. The new records included nine Cyanobacteria, as follows: Leptolyngbya angustissima (Figure 2), Microchaete uberrina (Figure 3), Nostochopsis lobatus (Figure 4), N. radians (Figure 5), Oscillatoria limosa (Figure 6), Phormidium amoenum (Figure 7), P. corium (Figure 8), Scytonema chiastum (Figure 9), and S. coactile (Figure 10). The remaining six records were Chlorophyta, as follows: Microspora pacbyderma (Figure 11), Ulotbrix tenuissima (Figure 12), Chaetophora elegans (Figure 13), Stigeoclonium lubricum (Figure 14), S. segarare (Figure 15), and $S$. setigerum (Figure 16). The following three taxa have not been previously recorded for stream habitats in the Hawaiian Islands, but have been recorded for other aquatic habitats: Nostoc linckia, Geitlerinema splendidum, and Terpsinoe musica. Although to our knowledge there are no published records of Nostochopsis radians and $N$. lobatus, we have examined and confirmed several specimens in the Bishop Museum (BISH 589120, 589136, 687629, 697637, and 92575) as these species.

Spirogyra sp. 1, Audouinella pygmaea, and Pbormidium retzii were the three most com- mon taxa collected in this study, and each occurred on all three islands sampled ( $\mathrm{O}^{\prime} \mathrm{ahu}$, Kaua' $i$, and Hawai'i) (Table 2). The chlorophyte Spirogyra sp. 1, characterized by a double helix chloroplast, was collected in $39 \%$ of the streams. In addition, Spirogyra sp. 1 had the greatest percentage cover in $33 \%$ of the streams in which it occurred. The red alga Audouinella pygmaea was collected in 34\% of the stream segments and had the greatest percentage cover in $38 \%$ of the streams in which it was sampled. The blue-green alga Pbormidium retzii was collected in $26 \%$ of the stream segments sampled, and in $57 \%$ of the streams in which it occurred it had the highest percentage cover. Two additional species, Cloniopbora plumosa and Hildenbrandia angolensis, were less abundant but still occurred on all three islands (Table 2). Twentysix taxa $(62 \%)$ were each only collected from one stream locality.

\section{DISCUSSION}

Two stream segments ( 8 and 11) on Kaua' $i$ appear to have exceptional habitat for macroalgae, with eight taxa recorded for each (Table 1). Seven of the 15 species observed in these two segments were new additions to the

Figures 2-16. New records of macroalgae for the Hawaiian Islands. Scale bar $=5 \mu \mathrm{m}$ unless otherwise noted. 2, Leptolyngbya angustissima bluish, noncapitate, unbranched filament without constrictions at the crosswalls (stream 5). 3, Microcbaete uberrina filament with terminal heterocysts (arrow) and constrictions common (stream 8). 4, Nostochopsis lobatus filaments with true branching (double arrowhead) forming a green gelatinous mat with hollow interior, increasing branching toward tip and lateral or terminal heterocysts (arrow) (stream 11). 5, Nostocbopsis radians filaments with true branching (double arrowhead) forming a green gelatinous mat, tapered tips radially arranged, branching does not increase toward tip, branches longer than in $N$. lobatus and lateral or terminal heterocysts present (arrow) (stream 2). 6, Oscillatoria limosa straight filament with cells much broader than long and end cell rounded with thickened membrane (stream 11). Scale bar $=15 \mu \mathrm{m} .7$, Pbormidium amoenum blue-green filament with constrictions at the crosswalls and a thin sheath extending past the tip (arrow) (stream 10). 8, Phormidium corium brownish green, nonconstricted filament, densely entangled, not capitate, midfilament cells longer than wide and pointy tip (stream 3). 9, Scytonema cbiastum blue-green, double false branching (double arrowhead) and heterocysts (arrow), quadrate cells with constrictions at the crosswalls and thick sheath present (stream 13). Scale bar $=20 \mu \mathrm{m} .10$, Scytonema coactile bluegreen filament with double false branching (double arrowhead) and heterocysts, no constrictions at the crosswalls, a thinner sheath, and shorter cells than $S$. chiastum (stream 8). Scale bar $=15 \mu \mathrm{m} .11$, Microspora pacbyderma green filament with $\mathrm{H}$-shaped, thick cell walls with chloroplasts folded, covering most of the cell (stream 12). Scale bar $=15 \mu \mathrm{m}$. 12, Ulotbrix tenuissima green filament composed of cylindrical cells shorter than wide and a broad, band-shaped chloroplast (stream 18). Scale bar $=15 \mu \mathrm{m}$. 13, Cbaetophora elegans green branched filament enclosed in a clear gelatinous ball with branches that end in a pointed tip (stream 11). Scale bar $=15 \mu \mathrm{m}$. 14, Stigeodonizun lubricum green branching filament with branches opposite or whorled, cells in the branches much smaller than in the main axis and end in a blunt point (stream 7). 15, Stigeoclonium segarare green branching filament with opposite or whorling branches, cells of main axis and primary branches same diameter with the first cell of the branch the longest, a parietal median band chloroplast present (stream 11). Scale bar $=10 \mu \mathrm{m}$. 16, Stigeocloninun setigertum yellowish green branched filament with alternate branching that is extremely prolonged before rebranching (stream 5). Scale bar $=10 \mu \mathrm{m}$. 
Hawaiian flora. As well, seven species were each collected in a single locality. These streams did not appear to be different from the other streams in the study in terms of water chemistry or physical parameters measured. Nevertheless, they seem to have high conservation value for biodiversity of macroalgae. Fortunately, one of the streams, Waipā Stream, is already part of the ahupua'a restoration project with Bishop Estate and Kamehameha Schools.

Four streams (stream numbers 12-15) were sampled in high-elevation bog areas of Kaua' $\mathrm{i}$ and showed a reduced $\mathrm{pH}$ with tannic waters (Table 1). We had hypothesized that the flora of these streams might differ in the species present. However, only two of the seven taxa identified were new records for the Hawaiian Islands. It is interesting that one of the newly recorded taxa, Microspora pachyderma, was present in three of the streams and may be restricted to that area.

Comparable numbers of stream segments were sampled on the three islands visited. However, the number of macroalgal samples collected and species identified differed greatly from island to island. Kaua'i had the greatest number of samples collected and species identified, followed closely by $\mathrm{O}^{\prime}$ ahu, with numbers for Hawai'i considerably lower (Table 2). The low numbers for Hawai i were also found in a previous study of the Hawaiian Islands but were attributed to the comparatively lower number of stream segments sampled on that island (Vis et al. 1994). These observations about the island of Hawai'i are in agreement with a recent study that showed the streams of Hawai' $i$ to be distinct from those of the other three main islands based on multivariate comparisons of the macroalgal flora composition (Sherwood 2002).

The overall average species richness recorded for this study was 3.9 macroalgae per stream segment. This result is higher than the previous reported for Hawaiian streams (3.4), North American tropical streams (3.1), or North American streams in general (3.1) (Sheath and Cole 1992, Vis et al. 1994). In addition, the mean species per segment for each island was either greater (Kaua $i=4.5$ and $\mathrm{O}^{\prime} \mathrm{ahu}=4.2$ ) or comparable (Hawai' $\mathrm{i}=$ 3.0). Therefore, as suggested by the earlier research, the species richness of the Hawaiian Islands does not seem to be affected by island size or distance from continental landmasses (Vis et al. 1994).

Vis et al. (1994) showed a significant correlation between stream size and algal percentage cover, which they attributed to reduced overhanging vegetation in wider streams. That previous study also discerned a positive relationship of species richness with maximum depth and species richness with specific conductance. However, none of these relationships was determined to be significant in the current study even though similar values were recorded for the water chemistry (temperature, $\mathrm{pH}$, and specific conductance).

Five streams visited in this study were also sampled in a previous study (Vis et al. 1994). Upon revisiting these streams, many of the taxa identified differed even though they were sampled during the same month (August). For stream 1, both studies reported Oedogonium sp. and Hildenbrandia angolensis, but the first visit yielded Scytonema myocbrous, Stigeoclonium stagnatile, and Compsopogon coeruleus and the current study collected Tolypotbrix tenuis, Cladophora glomerata, Basicladia cbelonum, and Audouinella pygmaea. In stream 3, Compsopogon coeruleus, Cloniopbora plumosa, Phormidium retzii, and $P$. corium were found in this study, but Tolypotbrix tenuis, Audouinella pygmaea, and Spirogyra sp. were recorded from the earlier study (Vis et al. 1994). For stream 9, Cladophora glomerata, Spirogyra sp., and Cloniophora plumosa were common to the two studies, but the current study recorded Hildenbrandia angolensis, which was not in the earlier study. Likewise, the earlier study identified Hydrosera whampoensis and Phormidium retzii, which were not collected in the current study. In stream 15, the current study identified Stigeoclonium subsecundum, Mougeotia sp., and Tabellaria flocculosa, and Vis et al. (1994) reported Spirogyra sp. and Phormidium subfuscum. Stream 16 yielded two species, Audouinella pygmaea and Geitlerinema splendidum. In the same stream Vis et al. (1994) 
recorded two species as well, Audouinella pygmaea and Compsopogon coeruleus. Some of these compositional differences may be due to the fact that although the same streams were visited in both studies, different reaches were most likely sampled. As well, macroalgae within a stream tend to be patchy, which may help explain some of the variation in taxa identified from each study. There may also have been environmental changes in the intervening $9 \mathrm{yr}$, such as Hurricane 'Iniki, which struck Kaua'i just months after the first survey was conducted.

The three most abundant taxa collected in the current study, Spirogyra sp. 1, Audouinella pygmaea, and Phormidium retzii, were also the most abundant taxa in the previous survey of stream macroalgae (Vis et al. 1994). Because the Spirogyra samples were not reproductive and therefore could not be identified to species it is difficult to ascertain if this is a single cosmopolitan taxon or a species complex. Audouinella pygmaea is a common inhabitant of streams in the coastal plains and tropical North America, as well as southeastern Brazil in South America (Necchi et al. 1993, Necchi and Zucchi 1995). Phormidium retzii has been noted to be the most common macroalga in North American streams as a whole, occurring in $32 \%$ of those in tropical regions (Sheath and Cole 1992). Therefore, it seems that at least the latter two taxa are good colonizers of suitable environments.

It appears that many algal taxa, especially those found throughout the Islands, have arrived via some manner and flourished in this environment. However, numerous questions still need to be answered, such as: Is their abundance due to one or many introductions from different continents? From which continent did these taxa arrive and is the source continent the same for each? Molecular markers such as internally transcribed spacer (ITS) sequence data and random amplified polymorphic DNA (RAPD) analyses could help in our understanding of algal dispersal to the Islands and will be fascinating research areas in the future. Last, molecular studies may reveal whether these algal morphospecies are genetically homogeneous or whether these taxa are Hawaiian endemics that merely resemble taxa from the continental landmasses. For example, it has been shown that Batracbospermum specimens from North America and Australia, which are currently indistinguishable by morphological characters, are not closely related ( $V$ is and Entwisle 2000).

This study identified 15 new records for the Hawaiian Islands (Figures 2-16) and 18 new records for streams of the Hawaiian Islands. Other taxa collected in the current study have been previously recorded in the aquatic habitats of the Hawaiian Islands (Nordstedt 1876, Tilden 1902, 1910, Lemmerman 1905, MacCaughey 1917, 1918a,b, Hustedt 1942, Fungladda et al. 1983, Vis et al. 1994, Sherwood et al. 2001a,b). A total of 281 species was identified in these studies in streams of the Hawaiian Islands. The current research extends the total number of records in streams of the Hawaiian Islands to 299 infrageneric taxa (including both micro- and macroalgae). The large number of taxa reported from this handful of studies suggests that more stream research is needed to fully catalog the Hawaiian stream algal diversity.

\section{ACKNOWLEDGMENTS}

We thank Dale Casamatta and Jeff Johansen for help in identification of Cyanobacteria. The Ohio University Foundation provided funding through an educational grant to M.L.V. and Harvey Ballard Jr. Aid in collecting is gratefully acknowledged from the following individuals: Robb Wienfurtner, Carolyn Reilly, Michele Van Atta, Harvey Ballard, Min Feng, and Andrea Gibson. Lei Wan, Adam Asquith, and Charlie McDonald were very helpful in finding stream localities for sampling.

\section{Literature Cited}

Fungladda, N., I. Kaczmarska, and S. R. Rushforth. 1983. A contribution to the freshwater diatom flora of the Hawaiian Islands. Bibl. Diatomol. 2:1-103. 
Geitler, L. 1932. Cyanophyceae. Pages 11196 in L. Rabenhorst, ed. Kryptogamenflora von Deutschland, Österreich und der Schweiz. Vol. 14. Akademische Verlagsgesellschaft, Leibzig.

Hintze, J. 2000. Number Cruncher statistical systems. Kaysville, Utah.

Hustedt, F. 1942. Susswasser-Diatomeen des indomalayischen Archipels und der Hawaii-Inseln. Int. Rev. Gesamten Hydrobiol. Hydrogr. 42:1-252.

Islam, A. K. M. N. 1963. A revision of the genus Stigeoclonium. Beih. Nova Hedwigia. Heft 10. Verlag Von J. Cramer, Weinheim. $164 \mathrm{pp}$.

Lemmerman, E. 1905. Die Algenflora der Sandwich-Inseln. Ergebnisse einer Reise nach dem Pacific. H. Schauinsland 1896/ 97. Engler's Bot. Jahrb. 34:607-632.

MacCaughey, V. 1917. The phytogeography of Manoa Valley, Hawaiian Islands. Am. J. Bot. 4:561-603.

. 1918a. Algae of the Hawaiian Archipelago. I. Bot. Gaz. 65:42-57.

. 1918b. Algae of the Hawaiian Archipelago. II. Bot. Gaz. 65:121-149.

Maciolek, J. A. 1969. II Lakes. 5. Oceania, New Zealand, Antarctica, freshwater lakes in Hawai'i. Verh. Int. Vereinigung Limnol. 17:386-391.

Necchi, O., Jr., R. G. Sheath, and K. M. Cole. 1993. Systematics of freshwater Audouinella (Acrochaetiaceae, Rhodophyta) in North America. 2. The bluish species. Algol. Stud. 71:13-21.

Necchi, O., Jr., and M. R. Zucchi. 1995. Systematics and distribution of freshwater Audouinella (Acrochaetiaceae, Rhodophyta) in Brazil. Eur. J. Phycol. 30:209-218.

Nordstedt, C. F. O. 1876. De Algae aquae dulcis et de Characeis ex insulis Sandvicensibus a Sv. Berggren 1875 reportatis. Minnesskrift Utgifven K. Fysiogr. Sallsk. Lund 7:1-24.

Pielou, E. C. 1979. Biogeography. Wiley, New York.

Prescott, G. W. 1962. Algae of the western Great Lakes area. W. C. Brown Publishers, Dubuque, Iowa. 977 pp.
Schoener, A. 1988. Experimental island biogeography. Pages 483-512 in A. A. Myers and P. S. Giller, eds. Analytical biogeography, an integrated approach to the study of animal and plant distributions. Chapman \& Hall, London.

Sheath, R. G., and K. M. Cole. 1992. Biogeography of stream macroalgae in North America. J. Phycol. 28:448-460.

Sheath, R. G., M. O. Morrison, J. E. Korch, D. Kaczmarczyk, and K. M. Cole. 1986. Distribution of stream macroalgae in south-central Alaska. Hydrobiologia 135: $259-269$

Sherwood, A. R. 2002. Macroalgal survey of the Hawaiian Islands: Taxonomy, distributional trends, and application to the study of native Hawaiian finfish. Final report to the Department of Land and Natural Resources, Hawai'i Division of Aquatic Resources. June.

Sherwood, A. R., M. H. Kido, and C. W. Morden. 2001a. New records of freshwater macroalgae from the Hawaiian Islands. 1. Chlorophyta. Rec. Hawaii Biol. Surv. (in press).

2001b. New records of freshwater macroalgae from the Hawaiian Islands. 2. Cyanophyta. Rec. Hawaii Biol. Surv. (in press).

Tilden, J. E. 1902. Collection of algae from the Hawaiian Islands. [Thrum's] Hawaii. Annu. 1902:106-113.

. 1910. Minnesota Algae. Vol. 1. The Myxophyceae of North America and adjacent regions including Central America, Greenland, Bermuda, the West Indies and Hawaii. Report of the Survey Botanical Series VIII. Minneapolis, Minnesota. 328 pp.

Vis, M. L., and T. J. Entwisle. 2000. Insight into the phylogeny of the $\mathrm{Ba}-$ trachospermales (Rhodophyta) from $r b c \mathrm{~L}$ sequence data of Australian taxa. J. Phycol. 36:1175-1182.

Vis, M. L., R. G. Sheath, J. A. Hambrook, and K. M. Cole. 1994. Stream macroalgae of the Hawaiian Islands: A preliminary study. Pac. Sci. 48:175-187. 


\section{Appendix}

Location of Hawaiian Sampling Sites

1 Mānoa Falls (Waihī Stream), Honolulu District, O'ahu

2 Rivulet, Scenic View, Old Pali Road, Ko'olau Poko District, O'ahu

3 Waihī Stream, Waihī Valley Nature Park, Kơolau Poko District, O'ahu

4 Ka'alaea Stream, Ko'olau Poko District, O'ahu

5 Uwao Stream, Ko'olau Poko District, O'ahu

6 Waiahu Stream, Ko'olau Poko District, O'ahu

7 Kahana Stream, Kahana State Park, Ko'olau Poko District, O'ahu

8 Waipā Stream, Hanalei District, Kaua'i

9 Limahuli Stream, Hanalei District, Kaua'i

10 Mānoa Stream, Hanalei District, Kaua'i

11 North fork of Wailua Stream, Kawaihau District, Kaua' $i$

12 Kawaikōī Stream tributary, Waimea District, Kaua 'i

13 Unnamed stream, Waimea District, Kaua'i

14 Kawaikōì Stream at Sugi Grove, Waimea District, Kaua'i

15 Stream on side of Waimea Canyon Road, Waimea District, Kaua'i

16 Stream at 'Akaka Falls, Puna District, Hawai'i

17 Niuli'i Stream, North Kohala District, Hawai' $i$

18 Route 250A at mile 9.38, Kawaihae Uka Bridge, South Kohala District, Hawai'i

19 Waikoloa Stream, South Kohala District, Hawai ${ }^{i}$

20 Stream near the ocean, Hāmākua District, Hawai'i

21 Stream near Kēokea State Park, North Kohala District, Hawai'i

22 Stream on road to Pololī Valley Lookout, North Kohala District, Hawai' $\mathrm{i}$

23 Stream near National Tropical Botanical Garden, South Hilo District, Hawai'i 